\title{
Elatostema qinzhouense (Urticaceae), a new species from limestone karst in Guangxi, China
}

\author{
Longfei Fu ${ }^{1,2}$, Alexandre K. Monro ${ }^{3}$, Tiange Yang ${ }^{4}$, Fang Wen $^{2}$, Bo Pan $^{2}$, Zibing Xin ${ }^{2}$, Zhixiang Zhang $^{\text {Corresp., } 1}$, \\ Yigang Wei ${ }^{\text {Corresp. } 2}$ \\ ${ }^{1}$ Laboratory of Systematic Evolution and Biogeography of Woody Plants, College of Nature Conservation, Beijing Forestry University, Beijing, China \\ 2 Guangxi Key Laboratory of Plant Conservation and Restoration Ecology in Karst Terrain, Guangxi Institute of Botany, Guangxi Zhuang Autonomous \\ Region and Chinese Academy of Sciences, Guilin, China \\ 3 Identification \& Naming Department, Royal Botanic Gardens, Kew, London, UK \\ ${ }^{4}$ College of Life Sciences \& Key Laboratory for Protection and Application of Special Plant Germplasm in Wuling Area of Hubei Province, South-Central \\ University for Nationalities, Wuhan, China
}

Corresponding Authors: Zhixiang Zhang, Yigang Wei

Email address: zxzhang@bjfu.edu.cn, weiyigang@aliyun.com

Elatostema qinzhouense L.F. Fu, A.K. Monro \& Y.G. Wei, a new species from Guangxi, China is described and illustrated. Morphologically, E. qinzhouense is most similar to $E$.

hezhouense from which it differs by having smaller size of leaf laminae, fewer and smaller staminate peduncle bracts, longer pistillate peduncle bracts and a larger achene. This result is supported by the molecular evidence. The phylogenetic position of the new species within Elatostema is evaluated using three DNA regions, ITS, trnH-psbA and psbM$\operatorname{trnD}$, for 107 taxa of Elatostema s.I. (including E. qinzhouense). Bayesian inference (BI) and maximum likelihood (ML) analyses each recovered the same strongly supported tree topologies, indicating that $E$. qinzhouense is a member of the core Elatostema clade and sister to $E$. hezhouense. Along with the phylogenetic studies, plastid genome and ribosomal DNA (rDNA) sequences of the new species are assembled and annotated. The plastid genome is $150,398 \mathrm{bp}$ in length and comprises two inverted repeats (IRs) of 24,688 bp separated by a large single-copy of 83,919 bp and a small single-copy of 17,103 bp. A total of 113 functional genes are recovered, comprising 79 protein-coding genes, 30 tRNA genes, and four rRNA genes. The rDNA is $5,804 \mathrm{bp}$ in length and comprised the $18 \mathrm{~S}$ ribosomal RNA partial sequence ( $1,809 \mathrm{bp}$ ), internal transcribed spacer 1 (213 bp), $5.8 \mathrm{~S}$ ribosomal RNA (164 bp), internal transcribed spacer 2 (248 bp) and 26S ribosomal RNA partial sequence $(3,370 \mathrm{bp})$. In addition, the chromosome number of $E$. qinzhouense is observed to be $2 n=26$, suggesting that the species is diploid. Given a consistent relationship between ploidy level and reproductive system in Elatostema, the new species is also considered to be sexually reproducing. Our assessment of the extinction threat for E. qinzhouense is that it is Endangered (EN) according to the criteria of the International Union for Conservation of Nature. 
1 Elatostema qinzhouense (Urticaceae), a new species from limestone karst in Guangxi, China

2 Longfei $\mathrm{Fu}^{1,2}$, Alexandre K. Monro ${ }^{3}$, Tiange Yang ${ }^{4}$, Fang $\mathrm{Wen}^{2}$, Bo Pan ${ }^{2}$, Zibing Xin ${ }^{2}$, Zhixiang 3 Zhang ${ }^{1}$, Yigang $\mathrm{Wei}^{2}$

41 Laboratory of Systematic Evolution and Biogeography of Woody Plants, College of Nature 5 Conservation, Beijing Forestry University, Beijing 100083, China

62 Guangxi Key Laboratory of Plant Conservation and Restoration Ecology in Karst Terrain,

7 Guangxi Institute of Botany, Guangxi Zhuang Autonomous Region and Chinese Academy of

8 Sciences, Guilin 541006, China

93 Identification \& Naming Department, Royal Botanic Gardens, Kew TW9 3AE, UK

104 College of Life Sciences \& Key Laboratory for Protection and Application of Special Plant

11 Germplasm in Wuling Area of Hubei Province, South-Central University for Nationalities,

12 Wuhan 430074, Hubei Province, China

14 Corresponding Authors:

15 Zhixiang Zhang ${ }^{1}$

16 No.35 Tsinghua East Road, Haidian District, Beijing, China

17 Email address: zxzhang@bjfu.edu.cn

18 Yigang $\mathrm{Wei}^{2}$

19 No.85 Yanshan Street, Yanshan District, Guilin, Guangxi, China

20 Email address: weiyigang $@$ aliyun.com 


\section{Abstract}

Elatostema qinzhouense L.F. Fu, A.K. Monro \& Y.G. Wei, a new species from Guangxi, China is described and illustrated. Morphologically, E. qinzhouense is most similar to E. hezhouense from which it differs by having smaller size of leaf laminae, fewer and smaller staminate peduncle bracts, longer pistillate peduncle bracts and a larger achene. This result is supported by the molecular evidence. The phylogenetic position of the new species within Elatostema is evaluated using three DNA regions, ITS, trnH-psbA and $p s b M-t r n D$, for 107 taxa of Elatostema s.l. (including E. qinzhouense). Bayesian inference (BI) and maximum likelihood (ML) analyses each recovered the same strongly supported tree topologies, indicating that E. qinzhouense is a member of the core Elatostema clade and sister to E. hezhouense. Along with the phylogenetic studies, plastid genome and ribosomal DNA (rDNA) sequences of the new species are assembled and annotated. The plastid genome is 150,398 bp in length and comprises two inverted repeats (IRs) of 24,688 bp separated by a large single-copy of 83,919 bp and a small single-copy of 17,103 bp. A total of 113 functional genes are recovered, comprising 79 protein-coding genes, 30 tRNA genes, and four rRNA genes. The rDNA is 5,804 bp in length and comprised the $18 \mathrm{~S}$ ribosomal RNA partial sequence (1,809 bp), internal transcribed spacer 1 (213 bp), 5.8S ribosomal RNA (164 bp), internal transcribed spacer 2 (248 bp) and 26S ribosomal RNA partial sequence $(3,370 \mathrm{bp})$. In addition, the chromosome number of E. qinzhouense is observed to be $2 n=26$, suggesting that the species is diploid. Given a consistent relationship between ploidy level and reproductive system in Elatostema, the new species is also considered to be sexually reproducing. Our assessment of the extinction threat for E. qinzhouense is that it is Endangered (EN) according to the criteria of the International Union for Conservation of Nature.

\section{Keyword}

Taxonomy, plastid genome, karst, phylogeny, karyotype, reproductive system 


\section{Introduction}

Elatostema J.R.Forst. \& G.Forst. is one of two species-rich genera in the Urticaceae, the other being Pilea Lindl. Elatostema comprises several hundred species of succulent herbs and subshrubs that grow in shade in forests, stream sides, gorges and caves (Fu et al., 2017a; Monro et al., 2018). Elatostema is distributed throughout tropical and subtropical Africa, Madagascar, Asia, Australia and Oceania (Lin, Friis \& Wilmot-Dear, 2003).

The delimitation of Elatostema has long been controversial with respect to Elatostematoides C.B.Rob., Pellionia Gaudich. and Procris Comm. ex Juss. A recent analysis of molecular and morphological evidence suggests that Elatostema is monophyletic and includes taxa attributed to Pellionia but excludes those attributed to Elatostematoides, Procris, and Pellionia repens (Lour.) Merr. (Tseng et al., 2019). The latest revision of Chinese Elatostema (Wang, 2014) indicates China, with more than 280 species, as the center of diversity for the genus but this may be an artefact of sampling and taxonomic effort (Fu et al., 2019a). Circa 2/3 (184 species) of Chinese Elatostema are associated with the limestone karst of Guangxi, Guizhou and Yunnan in Southwest China (Wang, 2014) and it is likely that limestone karst is an important source of species diversity and point endemics throughout its range.

Fu et al. (2019b) demonstrate that a large proportion of Elatostema species are known from a single collection, which increases the risk of the over-description of species (Wei, Monro \& Wang, 2011). DNA sequence data provides molecular evidence to confirm the relationship of undescribed species to described taxa and so can help mitigate this risk by enabling the closely related species to be identified (Fu et al., 2019b; Wells et al., 2021). For Chinese species, sequence data for 60 species ( $21 \%$ of the flora) are available for this purpose (Pers. Obs.).

Cytological data can also provide additional evidence to confirm generic placement in Urticaceae (Subramanian \& Thilagavathy, 1988; Kanemoto \& Yokota, 1998; Yamashiro et al., 2000; Kanemoto et al., 2015). Within Elatostema, it has also been successfully used for recognizing hybrid taxa (Tseng \& $\mathrm{Hu}, 2014$ ), as well as inferring ploidy and reproductive systems (Fu et al., 2017b). 
76

77

78

79

80

81

82

83

84

85

86

87

88

89

90

91

92

93

94

In 2014, while conducting field work in Guangxi, China, we found a hitherto undescribed species of Elatostema. The population comprised sterile plants with a distinctive and unfamiliar morphology. In order to obtain fertile plants of this taxon for identification, several individuals were collected to be introduced at Guilin Botanical Garden for further study. Once flowering, we were able to undertake a thorough literature survey and review of herbarium specimens at BM, IBK, IBSC, $\mathrm{K}$ and PE, along with the molecular and cytological studies. These confirmed that the material was of a hitherto undescribed species.

\section{Materials \& Methods}

Ethics statement

All the collecting locations of the new species reported in this study are outside any natural conservation area and no specific permissions were required for these locations. Since the species are currently undescribed, they are not currently included in the China Species Red List (Wang \& Xie, 2004). Our field studies did not involve any endangered or protected species. No specific permits were required for the present study.

\section{Nomenclature}

The electronic version of this article in Portable Document Format (PDF) will represent a published work according to the International Code of Nomenclature for algae, fungi, and plants (ICN), hence the new names contained in the electronic version are effectively published under that Code from the electronic edition alone. In addition, new names contained in this work which have been issued with identifiers by IPNI will eventually be made available to the Global Names Index. The IPNI can be accessed and the associated information contained in this publication viewed through any standard web browser using the web address http://ipni.org/. The online version of this work is archived and available from the following digital repositories: PeerJ, PubMed Central, and CLOCKSS. 
103

104

105

106

107

108

109

110

111

112

113

114

115

116

117

118

119

120

121

122

123

124

125

126

127

128

129

Morphological examination

We used the morphological species concepts of Wei, Monro \& Wang (2011), Fu et al. (2014), Wang (2014) and Fu et al. (2017a) to distinguish and compare taxa, placing emphasis on peduncle bract shape and length, the number, morphology and arrangement of the bracts comprising the receptacle-like involucre, the number of bracteoles per flower and leaf lamina length/width ratios. Material was examined using an Olympus SZX16 binocular microscope (Japan) and Plan Apo lens at $\times 10$ and $\times 90$ magnifications (Wei, Monro \& Wang, 2011). For achene morphology, we also made scanning electron micrograph (SEM) observations. Fruiting material was collected from specimens, dried, and mounted using double-sided adhesive tape and coated with gold using a sputter coater. The fruit were then observed and photographed under a ZEISS EVO18 scanning electron microscope. At least five achenes were used to determine their size and surface ornamentation.

\section{Extinction threat assessment}

An extinction threat assessment was undertaken for the new species described here using IUCN criteria (IUCN, 2001; IUCN, 2019). Calculations of the extent of occurrence (EOO) and area of occupation (AOO) were undertaken using the online conservation assessment tool GeoCATAT (Bachman et al., 2011). The AOO was calculated using a cell width of $2 \mathrm{~km}$ as recommended by IUCN (2019).

\section{Genomic DNA extraction and Sequencing}

Leaf material for DNA extraction was dried using silica gel (Chase \& Hills, 1991). Genomic DNA was extracted using a modified CTAB protocol (Chen et al., 2014) and assessed by agarose gel electrophoresis. The total gDNA sample was sent to Majorbio Company (http://www.majorbio.com/, China) for library construction and next-generation sequencing. Short-insert (350 bp) paired-end read libraries preparation and $2 \times 150 \mathrm{bp}$ sequencing were performed on an Illumina (HiSeq4000) genome analyzer platform. Approximately $2 \mathrm{~Gb}$ of raw 
130

131 by

132

133

134

135

136

137

138

139

140

141

142

143

144

145

146

147

148

149

150

151

152

153

154

155

156

data for the new species was filtered using the FASTX-Toolkit to obtain high-quality clean data by removing adaptors and low-quality reads (http://hannonlab.cshl.edu/fastx_toolkit/download.html).

\section{Plastid genome and ribosomal DNA (rDNA) assembly and annotation}

Clean reads were paired and imported in Geneious Primer (Kearse et al., 2012). For plastid genome assembly, the clean reads were mapped to published plastid genome sequence as reference (Fu et al., 2019c) using the Fine Tuning option in Geneious Primer (iterating set as 10 times) to exclude nuclear and mitochondrial reads. Then, de novo assembly was performed using Geneious Primer with a medium-low sensitivity setting to assemble plastid genome sequence. The generated contigs was mapped by the clean reads using the Fine Tuning option in Geneious Primer (iterating set as 10 times) to fill gaps. Contigs were able to be concatenated using the Repeat Finder option implemented in Geneious Primer until a $\sim 130 \mathrm{~kb}$ contig (including SSC, IR and LSC) being built. The Inverted repeat (IR) region was determined by the Repeat Finder option in Geneious Primer and was reverse copied to obtain the complete plastid genome. The annotation approach of plastid genome was performed using CPGAVAS2 and PGA (Qu et al., 2019; Shi et al., 2019). The process of rDNA assembly is generally same to plastid genome assembly with the exception of different reference (Gryta et al., 2017) and iterating as none. The annotation approach of rDNA was performed using Annotate option in Geneious Primer.

\section{Phylogenetic analyses}

We generated a phylogeny using sequences data from previous phylogenies of Elatostema s.l. (Tseng et al., 2019). We extracted three DNA regions (ITS, trnH-psbA and psbM-trnD) from assembled rDNA and complete plastid genome sequences, respectively of the new species and downloaded most of the sequences data used in Tseng et al. (2019) from Genbank (details see Table S1). This resulted in 107 taxa (116 accessions) of Elatostema s.l. as ingroup and three species, belonging to Lecanthus, Poikilopermum and Debregeasia, as outgroup. Three datasets 
157 (ITS, trnH-psbA and $p s b M$-trnD) were aligned independently using multiple alignment using fast 158 Fourier transform (MAFFT) version 7.0 (Katoh \& Standley, 2013) with default settings, 159 followed by manual adjustment. The two best supported tree topologies from maximum 160 likelihood (ML) analyses of cpDNA and nrITS were visually compared for topological 161 incongruence. A conflict in tree topologies of each tree was considered significant when 162 incongruent topologies both received bootstrap values $\geq 80 \%$ (Monro, 2006; Tseng et al., 2019).

163 As there was no significant incongruence between two datasets (Tseng et al., 2019), phylogenies 164 were reconstructed based on the combined dataset using ML and Bayesian inference (BI). The 165 BI and ML analyses were performed followed Tseng et al. (2019).

Cytological experiments

168 Stem cuttings of the new species were grown in tap-water in a culture room. Actively 169 growing root tips were harvested after 3-4 weeks. Cytological examination followed Fu et al. 170 (2017b). The best metaphase plates were photographed using an imager microscope with a camera attachment. At least 3-5 cells from 3-5 root tips of the new species at somatic metaphase were counted to determine the chromosome numbers.

\section{Results}

Characteristics of the complete plastid genome and ribosomal DNA

The complete plastid genome and ribosomal DNA (rDNA) sequences of Elatostema qinzhouense comprised 150,398 bp (Fig. 1) and 5,804 bp, respectively. The characteristics and statistics of plastid genome and rDNA were summarized in Table $1 \& 2$.

\section{Phylogenetic reconstruction}

The characteristics and statistics of the datasets used in this study are presented in Table 3. 
184 185

186

187

188

189

190

191

192

193

194

195

196

197

198

199

200

201

202

203

204

205

206

207

208

209

210

Elatostema ( $\mathrm{PP}=1, \mathrm{BP}=100 \%)$ and sister to E. hezhouense W.T.Wang, Y.G.Wei \& A.K.Monro $(\mathrm{PP}=1, \mathrm{BP}=100 \%)$ (Fig. 2).

\section{Chromosome characteristics}

The chromosome number of Elatostema qinzhouense was observed to be $2 \mathrm{n}=26$. The chromosome size fell into the range 1.45-3.33 $\mu \mathrm{m}$, suggesting slight size variation. Detailed karyotype analysis was not possible because the chromosomes were small and had unclear centromeres (Fig. 3).

\section{Taxonomic treatment}

Elatostema qinzhouense L.F. Fu, A.K. Monro \& Y.G. Wei, sp. nov. (Figs. 4-5 and S1) IPNI

Type. China. Guangxi: cultivated material in Guilin Botanical Garden harvested on 24 March 2017, wild-collected, from Taiping Town, Lingshan County, Qinzhou City, 22.408N, 108.835E (WGS84), elev. 124 m, 26 May 2014, Pan B and Ma HS P1184 (holotype IBK (IBK00426150!); isotype $\mathrm{K}(\mathrm{K} 000798321 !))$.

Diagnosis. Most similar to Elatostema hezhouense from which it differs by the smaller size of leaf laminae $(10-45 \times 6-15 \mathrm{~mm}$ vs. $55-115 \times 20-25 \mathrm{~mm})$, fewer and smaller staminate peduncle bracts $(1,1 \mathrm{~mm}$ vs. $2,3.5 \mathrm{~mm})$, longer pistillate peduncle bract $(0.900 \mathrm{~mm}$ vs. $0.375 \mathrm{~mm})$ and a larger achene $(0.86-0.94 \times 0.27-0.30 \mathrm{~mm}$ vs. $0.6 \times 0.25 \mathrm{~mm})($ see Table 4$)$.

Description. Perennial herb, epipetric, monoecious. Not tuber forming. Stem 150-270 $\times 1-2$ $\mathrm{mm}$, erect to arching, branched, drying finely sulcate, furfuraceous, glabrous, with internodes $6-$ $27 \mathrm{~mm}$. Stipules solitary, opposite the leaf at each node, persistent, $2-3 \times 0.75-1.5 \mathrm{~mm}$, narrowly lanceolate, glabrous. Leaves distichous, alternate, petioles $1-1.5 \times 0.5 \mathrm{~mm}$, glabrous; laminae 10-45 × 6-15 mm, length:width ratio 1.6-3.5:1, asymmetrically oblanceolate or falcate, chartaceous, 5-nerved, the secondary nerves $4-6$ pairs, $30-45^{\circ}$ to the midrib; upper surface drying green, furfuraceous, glabrous, cystoliths densely scattered, fusiform, $0.2-0.5 \mathrm{~mm}$; lower 
211 surface drying yellow-green, furfuraceous glabrous, sparsely brown glandular, cystoliths absent;

212 base asymmetrical, broader-half auriculate, narrower-half cuneate; margin serrate-dentate, teeth

213 3-5 mm apart; apex acuminate. Staminate and pistillate inflorescences borne on the same stems

214 concurrently. Staminate inflorescences solitary, 5-7 mm, bearing 2-4 flowers in a receptacle-like

215 involucre; peduncle ca $0.9 \times 0.5 \mathrm{~mm}$, glabrous, bracteate; bract $1 \mathrm{~mm}$, deltate; receptacle ca 2.5

$216 \times 1 \mathrm{~mm}$, oblong, not lobed, glabrous, subtended by marginal bracts, marginal bracts 6, unequal,

217 outer major bracts 2, inner minor bracts 4; major bracts 4-5 mm, broadly ovate, the apex

218 corniculate, minor bracts ca $5 \mathrm{~mm}$, ovate. Staminate flowers $2.5-3 \times 2 \mathrm{~mm}$, white, pedicellate,

219 pedicel 1.5-2.0 mm; bracteoles 2, equal, 2-3 mm, narrowly lanceolate or linear; tepals 4 or 5, the

220 subapical appendage $1.0 \mathrm{~mm}$, corniculate, green. Pistillate inflorescences solitary, 5-6 mm,

221 bearing more than 40 flowers in a pedunculate receptacle-like involucre; peduncle ca $1.0 \times 0.8$

$222 \mathrm{~mm}$, glabrous, bracteate; bracts $0.9 \mathrm{~mm}$, deltate, furfuraceous; receptacle-like involucre $1-1.5 \times$

223 2.5-3.0 mm, subquadrate, not lobed, glabrous, subtended by marginal bracts, the bracts unequal,

224 dark green, furfuraceous, major bracts $2,1.2-1.5 \mathrm{~mm}$, broadly ovate, with a raised dorsal midrib,

225 the apex corniculate, minor bracts $8,1.0-1.2 \mathrm{~mm}$, ovate, the apex corniculate. Pistillate flowers

226 pedicellate; pedicel subsessile; bracteoles 2, equal, 1.0-1.3 mm, narrowly lanceolate or linear.

227 Infructescences as pistillate inflorescences; achene 0.86-0.94 $\times 0.27-0.30 \mathrm{~mm}$, length:width

228 ratio 3.07-0.31:1, oblongoid, pale brown, with 8 narrow longitudinal ridges.

229 Distribution and habitat. Elatostema qinzhouense is known from a single locality in Lingshan

230 County, Qinzhou City, Guangxi, China. E. qinzhouense is likely calcicolous and grows under

231 evergreen broad-leaved forest on limestone hills. Flowering from December to March, fruiting

232 from March to April.

233 Etymology. Elatostema qinzhouense is named after the type locality, Qinzhou City, Guangxi

234 Zhuang Autonomous Region, China.

235 Vernacular name. 钦州楼梯草 (Chinese name).

236 Additional specimen examined (paratype). China. Guangxi: cultivated material in Guilin

237 Botanical Garden harvested on 27 January 2019, wild-collected, from Taiping Town, Lingshan 
238 County, Qinzhou City, 22.408N, 108.835E (WGS84), elev. 124 m, 26 May 2014, Pan B and Ma 239 HS P1184 (paratypes BJFC!, CSH!, PE!).

240 Conservation Assessment. Elatostema qinzhouense is known from a single locality (AOO 4 $241 \mathrm{~km}^{2}$, criteria B2). At this locality the population of this species comprises ca 200 mature 242 individuals (criteria D1). The only observed population is at the edge of agricultural land on a 243 small limestone hill, which, although deforested in the past, appears not to be actively disturbed. 244 According to IUCN (2001) and IUCN (2019) E. qinzhouense could be considered Critically 245 Endangered (CR) according to criteria D1 and B2. Botanically, this part of Guangxi is relatively 246 poorly explored and so it may be that other populations exist that have yet to be observed. Given 247 the frequency of point-endemics in the genus the opposite is also possible. Given the lack of 248 imminent threat and this species resilience to past deforestation, and the frequency of point249 endemics amongst karst-associated Elatostema suggesting that this species may not have been subject to a large reduction in population size we re-appraise E. qinzhouense as Endangered (EN).

252

253

254

255

256

257

258

259

260

261

262

263

264

\section{Discussion}

All known Elatostema species from China have the basic chromosome number $\mathrm{x}=13$ (Yamashiro et al., 2000; Tseng \& Hu, 2014; Fu et al., 2017b). Our chromosome count for E. qinzhouense of $2 \mathrm{n}=26$. Fu et al. (2017b) proposed a consistent relationship between ploidy level and reproductive system in Elatostema whereby diploid and triploid species are sexual and apomictic respectively. Our observations, therefore, suggest that E. qinzhouense is a diploid and reproduces sexually (Fu et al., 2017b).

Our phylogenetic analysis of DNA sequence data suggest that Elatostema qinzhouense belongs to the Core Elatostema clade (Tseng et al., 2019) and that it is most closely related to $E$. hezhouense, a cave dwelling species endemic to Guangxi (Wei, Monro \& Wang, 2011). Geographically, the localities of two species are more than $400 \mathrm{~km}$ apart which suggest that there is little opportunity for gene flow as they are wind-pollinated and inhabit deeply dissected mountainous terrain. Morphologically, E. qinzhouense is most similar to E. hezhouense from 
265

266

267

268

269

270

271

272

273

274

275

276

277

278

279

280

281

282

283

284

285

286

287

288

289

290

291

which it differs by having smaller leaf laminae, fewer and smaller staminate peduncle bracts, longer pistillate peduncle bracts and a larger achene (see Table 4).

It is worth noting that one of the diagnostic characters for E. qinzhouense, the morphology of the peduncle bract, has not been included in previous revisions of Chinese Elatostema (Wang, 1980; Wang \& Chen, 1995; Lin, Friis \& Wilmot-Dear, 2003; Wang, 2014). This character has been useful for the characterization of species of Pilea (Monro, 2001) and on this basis was applied to Elatostema (Wei, Monro \& Wang, 2011). Tseng et al. (2019) demonstrated that characters used by Wang $(1980,2014)$ to delimit infrageneric classes in the genus, whilst useful for species identification, were not phylogenetically informative and so exploring additional, potentially informative morphological characters, such as peduncular bract, for species delimitation and infrageneric classification should be a priority.

\section{Conclusions}

This study is the first attempt to confirm and describe a new species of Elatostema based on a combination of morphological, molecular and cytological evidence. The reported plastid genome and chromosome number provide informative data to support further studies on the systematics, evolution and conservation of the genus. We propose that recognizing and describing new species based on the integration of morphological, molecular and cytological data; observations will result in more robust and rational taxa (Hong, 2016).

\section{Acknowledgements}

We are grateful to Hu-Sheng Ma (GXIB) for joining the fieldtrip, Yu-Jing Wei (GXIB) for SEM experiments and Juliet Beentje $(\mathrm{K})$ for the illustration. This work was supported by National Natural Science Foundation of China (31860042), Light of West China Program of the Chinese Academic of Sciences ([2020]59), Guangxi Natural Science Foundation Program (2017GXNSFBA198014) and the Botanical Illustration fund of RBG Kew. 
292

293

294

295

296

297

298

299

300

301

302

303

304

305

306

307

308

309

310

311

312

313

314

315

316

\section{References}

Bachman S, Moat J, Hill AW, de la Torre J, Scott B. 2011. Supporting Red List threat assessments with GeoCATAT: geospatial conservation assessment tool. In: Smith, V., \& Penev, L. (Eds.), e-Infrastructures for data publishing in biodiversity science. ZooKeys 150: 117-126, and GeoCATAT. Geospatial Conservation Assessment Tool. [On line]. http://geocat.kew.org/ (accessed 10 Dec. 2018).

Chase MW, Hills H. 1991. Silica gel: An ideal material for field preservation of leaf samples for DNA studies. Taxon 40(2): 215-220 DOI 10.2307/1222975.

Chen LY, Song MS, Zha HG, Li ZM. 2014. A modified protocol for plant genome DNA extraction. Plant Diversity and Resources 36: 375-380 DOI 10.7677 /ynzwyj201413156.

Fu LF, Do VT, Wen F, He CX. 2014. Elatostema arcuatobracteatum (Urticaceae), a new species from Vietnam. Phytotaxa 174: 111-115 DOI 10.11646/phytotaxa.174.2.6.

Fu LF, Monro A, Do VT, Nuraliev MS, Averyanov LV, Wen F, Xin ZB, Maisak TV, Kuznetsov AN, Kuznetsova SP, Nguyen KS, Wei YG. 2019a. Checklist to the Elatostema (Urticaceae) of Vietnam including 19 new records, ten new combinations, two new names and four new synonyms. PeerJ 6: e6188 DOI 10.7717/peerj.6188.

Fu LF, Monro AK, Huang SL, Wen F, Wei YG. 2017a. Elatostema tiechangense (Urticaceae), a new cave-dwelling species from Yunnan, China. Phytotaxa 292(1): 085-090 DOI 10.11646/phytotaxa.292.1.9.

Fu LF, Monro AK, Wen F, Xin ZB, Wei YG, Zhang ZX. 2019b. The rediscovery and delimitation of Elatostema setulosum W.T.Wang (Urticaceae). Phytokeys 126: 79-88 DOI $10.3897 /$ phytokeys.126.35707.

Fu LF, Su LY, Mallik A, Wen F, Wei YG. 2017b. Cytology and sexuality of 11 species of Elatostema (Urticaceae) in limestone karsts suggests that apomixis is a recurring phenomenon. Nordic Journal of Botany 35: 251-256 DOI 10.1111/njb.01281. 
317 Fu LF, Xin ZB, Wen F, Li S, Wei YG. 2019c. Complete chloroplast genome sequence of 318 Elatostema dissectum (Urticaceae). Mitochondrial DNA Part B, Resources 4(1): 838-839 DOI 10.1080/23802359.2019.1567292.

Gryta H, Van de Paer C, Manzi S, Holota H, Roy M, Besnard G. 2017. Genome skimming and plastid microsatellite profiling of alder trees (Alnus spp., Betulaceae): phylogenetic and phylogeographical prospects. Tree Genetics \& Genomes 13: 118 DOI 10.1007/s11295-0171204-2.

Hong D. 2016. Opinion of raising rationality in species delimitation. Biodiversity Science 24(3): 360-361 DOI 10.17520/biods.2016075.

IUCN [International Union for Conservation of Nature and Natural Resources Species Survival Commission]. 2001. IUCN Red List Categories: Version 3.1. International Union for Conservation of Nature and Natural Resources, Gland and Cambridge, pp. 70.

IUCN Standards and Petitions Subcommittee. 2019. Guidelines for using the IUCN Red List Categories and Criteria. Version 14. Prepared by the Standards and Petitions Subcommitttee. Available from: http://www.iucnredlist.org/documents/RedListGuidelines.pdf

Kanemoto A, Yokota M. 1998. Chromosome numbers of four species of Elatostema (Urticaceae) of the Ryukyus. Journal of Phytogeography and Taxonomy 45: 29-31.

Kanemoto T, Shiuchi T, Lu YX, Nakata M, Guan KY. 2015. Karyomorphology of Elatostema salvinioides W.T. Wang (Urticaceae). Bulletin of the Botanic Gardens of Toyama 20: 1-6.

Katoh K, Standley DM. 2013. MAFFT multiple sequence alignment software version 7: improvements in performance and usability. Molecular Biology and Evolution 30: 772-780 DOI 10.1093/molbev/mst010.

Kearse M, Moir R, Wilson A, Stones-Havas S, Cheung M, Sturrock S, Buxton S, Cooper A, Markowitz S, Duran C, Thierer T, Ashton B, Meintjes P, Drummond A. 2012. Geneious Basic: an integrated and extendable desktop software platform for the organization and analysis of sequence data. Bioinformatics 28: 1647-1649 DOI 10.1093/bioinformatics/bts 199. 
344 Lin Q, Friis I, Wilmot-Dear MC. 2003. Pellionia \& Elatostema. In: Wu Z, Raven PH, eds. Flora 345 of China. Vol. 5. Beijing: Science Press, St. Louis: Missouri Botanical Garden Press, 74346 189.

347

348

349

350

351

352

353

354

355

356

357

358

359

360

361

362

363

364

365

366

367

368

369

370

Monro AK, Bystriakova N, Fu L, Wen F, Wei Y. 2018. Discovery of a diverse cave flora in China. PLoS One 13(2): e0190801 DOI 10.1371/journal.pone.0190801.

Monro, AK. 2001. Synopsis of Mesoamerican Pilea (Urticaceae), including eighteen typifications and a key to the species. Bulletin of the Natural History Museum London, Botany 31: 9-25.

Monro, AK. 2006. Revision of species-rich genera: a phylogenetic framework for the strategic revision of Pilea (Urticaceae) based on cpDNA, nrDNA, and morphology. American Journal of Botany 93: 426-441 DOI 10.3732/ajb.93.3.426.

Qu X, Moore MJ, Li D, Yi T. 2019. PGA: a software package for rapid, accurate, and flexible batch annotation of plastomes. Plant Methods 15(1): 50 DOI 10.1186/s13007-019-0435-7.

Shi L, Chen H, Jiang M, Wang L, Wu X, Huang L, Liu C. 2019. CPGAVAS2, an integrated plastome sequence annotator and analyzer. Nucleic Acids Research 47(W1): W65-W73 DOI 10.1093/nar/gkz345.

Subramanian D, Thilagavathy A. 1988. Cytotaxonomical studies of south Indian Urticaceae. Cytologia 53: 671-678.

Tseng YH, Hu JM. 2014. A new hybrid from Taiwan, Elatostema $\times$ hybrida (Urticaceae), is the first confirmed natural hybrid for Urticaceae. Phytotaxa 161: 43-60 DOI 10.11646/phytotaxa.161.1.2.

Tseng YH, Monro AK, Wei YG, Hu JM. 2019. Molecular phylogeny and morphology of Elatostema s.1. (Urticaceae): implications for inter- and infrageneric classification. Molecular Phylogenetics and Evolution 132: 251-264 DOI 10.1016/j.ympev.2018.11.016.

Wang S, Xie Y. 2004. China species red list 1: red List. Beijing: Higher Education Press.

Wang WT, Chen CJ. 1995. Pellionia \& Elatostema. In: Wang WT, Chen CJ, eds. Flora Reipublicae Popularis Sinicae. Vol. 23. Beijing: Science Press, 160-317. 
371 Wang WT. 1980. Classificatio specierum Sinicarum Elatostematis (Urticaceae). Bulletin of 372 Botanical Laboratory of North-Eastern Forestry Institute 7: 40-41, 49-50.

373 Wang WT. 2014. Elatostema (Urticaceae) in China. Qingdao Publishing House Qingdao.

374 Wei YG, Monro AK, Wang WT. 2011. Additions to the Flora of China: seven new species of 375 Elatostema (Urticaceae) from the karst landscapes of Guangxi and Yunnan. Phytotaxa $376 \quad 29: 1-27$ DOI 10.11646/phytotaxa.29.1.1.

377 Wells T, Maurin O, Dodsworth S, Friis I, Cowan R, Epitawalage N, Brewer G., Forest F, Baker 378 WJ, Monro AK. 2021. Combination of Sanger and target-enrichment markers supports 379 revised generic delimitation in the problematic 'Urera clade' of the nettle family 380 (Urticaceae). Molecular Phylogenetics and Evolution DOI 10.1016/j.ympev.2020.107008.

381 Yamashiro T, Kanemoto T, Denda T, Yokota M. 2000. Chromosome number variation in 382 Elatostema suzuki (Urticaceae), a species endemic to Okinawa Island, the Ryukys. Acta $383 \quad$ Phytotaxonomica et Geobotanica 51: 21-29. 
386

387

388

389

390

391

392

393

394

395

396

397

398

399

400

401

402

403

404

405

406

407

408

409

410

411

412

Table 1. Summary of plastid genome and rDNA of Elatostema qinzhouense

Table 2. Genes encoded in plastid genome of Elatostema qinzhouense

Table 3. Statistics for the molecular datasets used in this study

Table 4. Diagnostic comparison of Elatostema qinzhouense and E. hezhouense

Figure caption:

Figure 1. Plastid genome map of Elatostema qinzhouense. The thick lines on the outer complete circle identify the inverted repeat regions (IRa and IRb). The innermost track of the plastome shows the GC content. Genes on the outside and inside of the map are transcribed in clockwise and counter directions, respectively.

Figure 2. Phylogenetic tree of Elatostema s.1. generated from Bayesian Inference (BI) of combined dataset (ITS, trnH-psbA and psbM-trnD). Numbers on the branches indicate the posterior probability $(\geq 0.5)$ of BI and bootstrap values $(\geq 50 \%)$ of the ML analyses.

Figure 3. Micromorphology of achene and somatic chromosomes at metaphase of Elatostema qinzhouense: (A) achene from LM observation (Scale bar = $1 \mathrm{~mm}$ ); (B) achene from SEM observation (Scale bar $=200 \mu \mathrm{m}) ;(C)$ achene surface from SEM observation (Scale bar $=20$ $\mu \mathrm{m})$; (D-F) somatic chromosome observation (Scale bar $=10 \mu \mathrm{m})$.

Figure 4. Illustration of Elatostema qinzhouense. (A) habit; (B) staminate and pistillate inflorescences at subsequent nodes of monoecious stem; (C) stipule and furfuraceous stem; (D) leaves; (E) staminate inflorescence viewed from below showing involucre bracts; (F) staminate 
413 flower; (G) pistillate inflorescence viewed from below showing involucre bracts; $(\mathrm{H})$ achene. 414 Illustration by Juliet Beentje.

415

416 Figure 5. Plate of Elatostema qinzhouense: (A) habitat; (B) habit; (C) leave base and stipule; (D) 417 staminate inflorescence; (E) staminate flower; (F) pistillate inflorescence. Photos by Long-Fei Fu 418 \& Bo Pan.

419 


\section{Table $\mathbf{1}$ (on next page)}

Summary of plastid genome and rDNA of Elatostema qinzhouense

Table 1. Summary of plastid genome and rDNA of Elatostema qinzhouense 
1 Table 1. Summary of plastid genome and rDNA of Elatostema qinzhouense

\begin{tabular}{lll}
\hline Characteristic & Elatostema qinzhouense \\
\hline Plastid genome & Size (base pair, bp) & 150,398 \\
& LSC length (bp) & 83,919 \\
& SSC length (bp) & 17,103 \\
& IR length (bp) & 24,688 \\
& Number of genes & 113 \\
& Protein-coding genes & 79 \\
& rRNA genes & 4 \\
tRNA genes & 30 \\
& LSC GC\% & $33.75 \%$ \\
SSC GC\% & $29.82 \%$ \\
& IR GC\% & $43.00 \%$ \\
\hline Size (bp) & 5,804 \\
18S ribosomal RNA partial sequence (bp) & 1,809 \\
internal transcribed spacer 1 (bp) & 213 \\
& 5.8S ribosomal RNA (bp) & 164 \\
internal transcribed spacer 2 (bp) & 248 \\
26S ribosomal RNA partial sequence (bp) & 3,370 \\
\hline
\end{tabular}

2 


\section{Table 2 (on next page)}

Genes encoded in plastid genome of Elatostema qinzhouense

Table 2. Genes encoded in plastid genome of Elatostema qinzhouense 
1 Table 2. Genes encoded in plastid genome of Elatostema qinzhouense

\begin{tabular}{|c|c|}
\hline Group of Genes & Gene Name \\
\hline tRNA genes & $\begin{array}{l}\operatorname{trn} H-G U G, \operatorname{trn} K-U U U^{*}, \operatorname{trn} Q-U U G, \operatorname{trn} S-G C U, \operatorname{trn} G-U C C^{*}, \operatorname{trn} R-U C U, \\
\operatorname{trn} C-G C A, \operatorname{trn} D-G U C, \operatorname{trn} Y-G U A, \operatorname{trn} E-U U C, \operatorname{trn} T-G G U, \operatorname{trn} S-U G A, \operatorname{trn} G- \\
G C C, \operatorname{trn}{ }^{-} M-C A U, \operatorname{trn} S-G G A, \operatorname{trn} T-U G U, \operatorname{trn} L-U A A^{*}, \operatorname{trn} F-G A A, \operatorname{trn} V- \\
U A C^{*}, \operatorname{trn} M-C A U, \operatorname{trn} W-C C A, \operatorname{trn} P-U G G, \operatorname{trn} I-C A U(\times 2), \operatorname{trn} L-C A A(\times 2), \\
\operatorname{trn} V-G A C(\times 2), \quad \operatorname{trn} I-G A U^{*}(\times 2), \operatorname{trn} A-U G C^{*}(\times 2), \operatorname{trn} R-A C G(\times 2), \operatorname{trn} N- \\
G U U(\times 2), \operatorname{trn} L-U A G\end{array}$ \\
\hline rRNA genes & $\begin{array}{l}r r n 16(\times 2), r r n 23(\times 2), r r n 4.5(\times 2), r r n 5(\times 2) \\
r p s 16^{*}, r p s 2, r p s 14, r p s 4, r p s 18, r p s 12^{* *}(\times 2), r p s 11, r p s 8, r p s 3, r p s 19,\end{array}$ \\
\hline Ribosomal small subunit & $r p s 7(\times 2), r p s 15$ \\
\hline Ribosomal large subunit & rpl33, rpl32, rpl20, rpl36, rpl14, rpl16*, rpl22, rpl2*(×2), rpl23(×2) \\
\hline DNA-dependent RNA polymerase & гроС2, гроС1*, гров, гро A \\
\hline Photosystem I & psaB, psaA, psaI, psaJ, psaC \\
\hline Large subunit of rubisco & $r b c L$ \\
\hline Photosystem II & $\begin{array}{l}p s b A, p s b K, p s b I, p s b M, p s b C, p s b Z, p s b G, p s b J, p s b L, p s b F, p s b E, p s b B, \\
p s b T, p s b N, p s b H \\
n d h J, n d h K, n d h C, n d h B^{*}(\times 2), n d h F, n d h D, n d h E, n d h G, n d h I, n d h A^{*},\end{array}$ \\
\hline NADH dehydrogenase & $n d h H$ \\
\hline Cytochrome b/f complex & $\operatorname{pet} N, \operatorname{pet} A, \operatorname{pet} L, \operatorname{pet} G, \operatorname{pet} B^{*}, \operatorname{pet} D^{*}$ \\
\hline ATP synthase & $\operatorname{atp} A, \operatorname{atp} F^{*}$, atpH, atpI, atpE, atpB \\
\hline Maturase & matK \\
\hline Subunit of acetyl-CoA carboxylase & $a c c D$ \\
\hline Envelope membrane protein & $\operatorname{cem} A$ \\
\hline Protease & $\operatorname{clp} P^{* *}$ \\
\hline C-type cytochrome synthesis & $\operatorname{ccs} A$ \\
\hline Conserved open reading frames (ycf) & $y c f 3^{* *}, y c f 4, y c f 2(\times 2), y c f 1, y c f 15(\times 2)$ \\
\hline
\end{tabular}

Genes with one or two introns are indicated by one $(*)$ or two asterisks $(* *)$, respectively. Genes in the IR regions are followed by the $(\times 2)$ symbol. 


\section{Table 3 (on next page)}

Statistics for the molecular datasets used in this study

Table 3. Statistics for the molecular datasets used in this study 
1 Table 3. Statistics for the molecular datasets used in this study

\begin{tabular}{ccccccc}
\hline & $\begin{array}{c}\text { Number of } \\
\text { sequences } \\
\text { (ingroup/outgroup) }\end{array}$ & $\begin{array}{c}\text { Aligned } \\
\text { length } \\
(\mathrm{bp})\end{array}$ & $\begin{array}{c}\text { Length } \\
\text { variation } \\
(\mathrm{bp})\end{array}$ & $\begin{array}{c}\text { Variable } \\
\text { characters } \\
(\mathrm{bp})\end{array}$ & $\begin{array}{c}\text { Parsimony- } \\
\text { informative } \\
\text { characters (bp) }\end{array}$ & $\begin{array}{c}\text { Model } \\
\text { selected } \\
\text { (AIC) }\end{array}$ \\
\hline ITS & $118 / 3$ & 887 & $571-710$ & 569 & 484 & - \\
trnH- $p$ s $b A$ & $118 / 3$ & 370 & $174-263$ & 196 & 128 & - \\
$p s b M-$ trnD & $118 / 3$ & 645 & $329-522$ & 254 & 129 & - \\
Combined plastid & $118 / 3$ & 1,015 & $503-767$ & 450 & 257 & - \\
Combined all & $118 / 3$ & 1,902 & $1,170-1,416$ & 1,020 & 741 & GTR+I+G \\
\hline
\end{tabular}

\section{2}


Table 4 (on next page)

Diagnostic comparison of Elatostema qinzhouense and $\mathrm{E}$. hezhouense

Table 4. Diagnostic comparison of Elatostema qinzhouense and $\mathrm{E}$. hezhouense 
1 Table 4. Diagnostic comparison of Elatostema qinzhouense and E. hezhouense

\begin{tabular}{lll}
\hline Characters & E. qinzhouense & E. hezhouense \\
\hline leaf laminae & $10-45 \times 6-15 \mathrm{~mm}$ & $55-115 \times 20-25 \mathrm{~mm}$ \\
staminate peduncle bract & $1,1 \mathrm{~mm}$ & $2,3.5 \mathrm{~mm}$ \\
pistillate peduncle bract & $0.900 \mathrm{~mm}$ & $0.375 \mathrm{~mm}$ \\
achene & $0.86-0.94 \times 0.27-0.30$ & $0.6 \times 0.25$ \\
\hline
\end{tabular}

2 


\section{Figure 1}

Plastid genome map of Elatostema qinzhouense.

Figure 1. Plastid genome map of Elatostema qinzhouense. The thick lines on the outer complete circle identify the inverted repeat regions (IRa and IRb). The innermost track of the plastome shows the GC content. Genes on the outside and inside of the map are transcribed in clockwise and counter directions, respectively. 


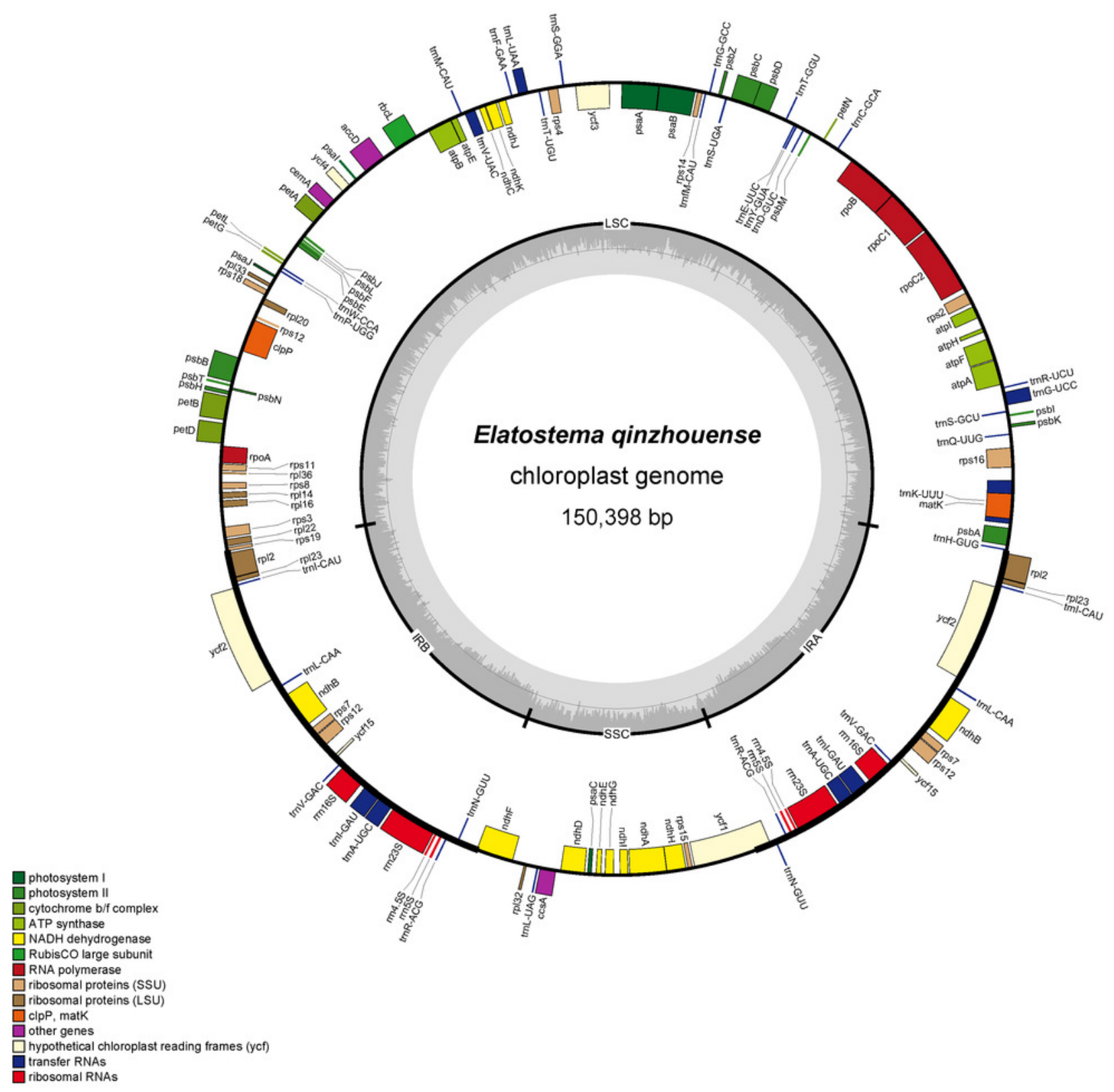


Figure 2

Phylogenetic tree of Elatostema s.I. generated from Bayesian Inference (BI) of combined dataset (ITS, trnH-psbA and psbM-trnD)

Figure 2. Phylogenetic tree of Elatostema s.l. generated from Bayesian Inference (BI) of combined dataset (ITS, trnH-psbA and psbM-trnD). Numbers on the branches indicate the posterior probability $(\geq 0.5)$ of $\mathrm{BI}$ and bootstrap values $(\geq 50 \%)$ of the $\mathrm{ML}$ analyses. 


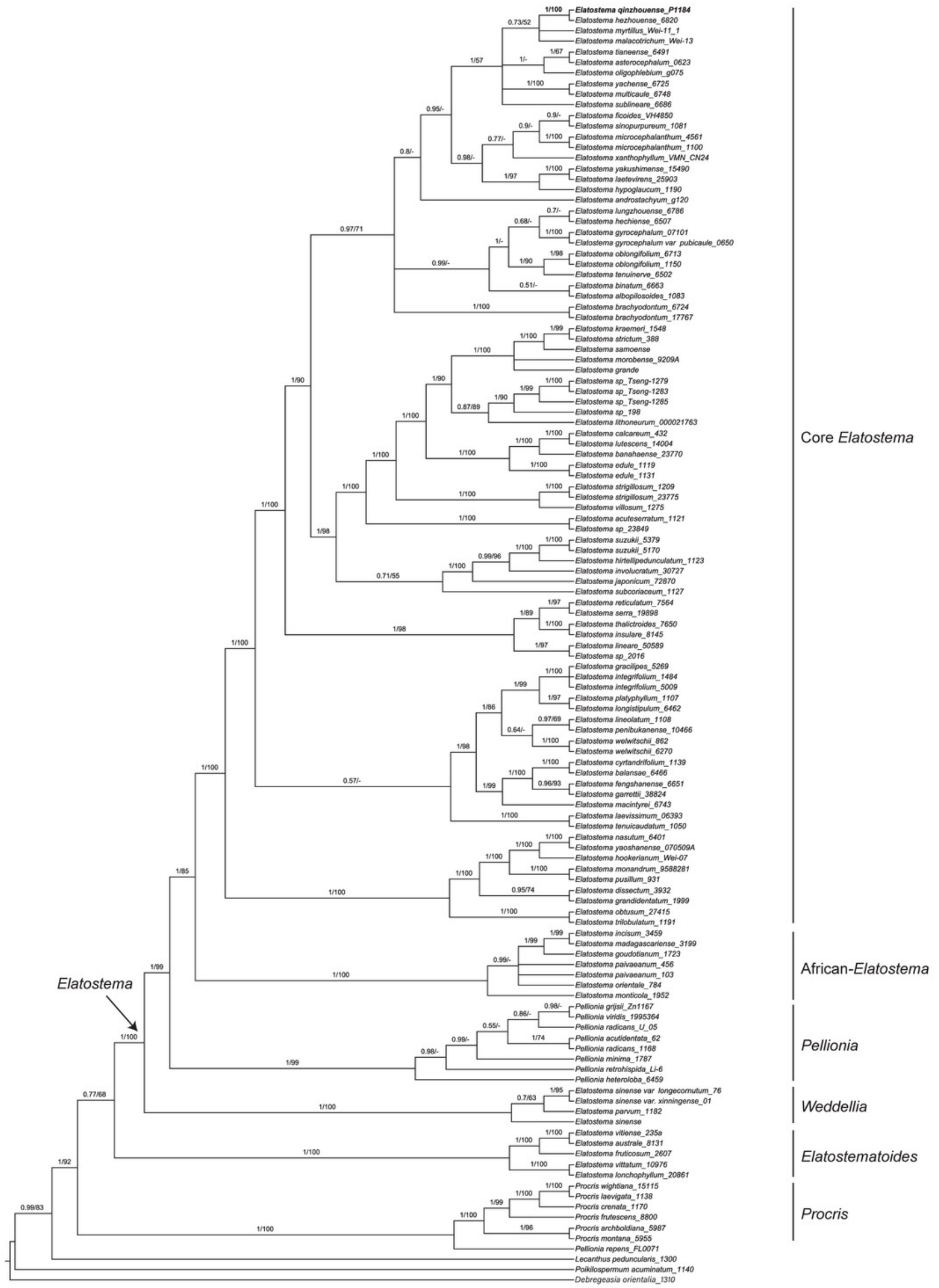




\section{Figure 3}

Micromorphology of achene and somatic chromosomes at metaphase of Elatostema qinzhouense

Figure 3. Micromorphology of achene and somatic chromosomes at metaphase of Elatostema qinzhouense: (A) achene from LM observation (Scale bar = $1 \mathrm{~mm}$ ); (B) achene from SEM observation (Scale bar $=200 \mu \mathrm{m})$; (C) achene surface from SEM observation (Scale bar $=20$ $\mu \mathrm{m})$; (D-F) somatic chromosome observation (Scale bar $=10 \mu \mathrm{m}$ ).

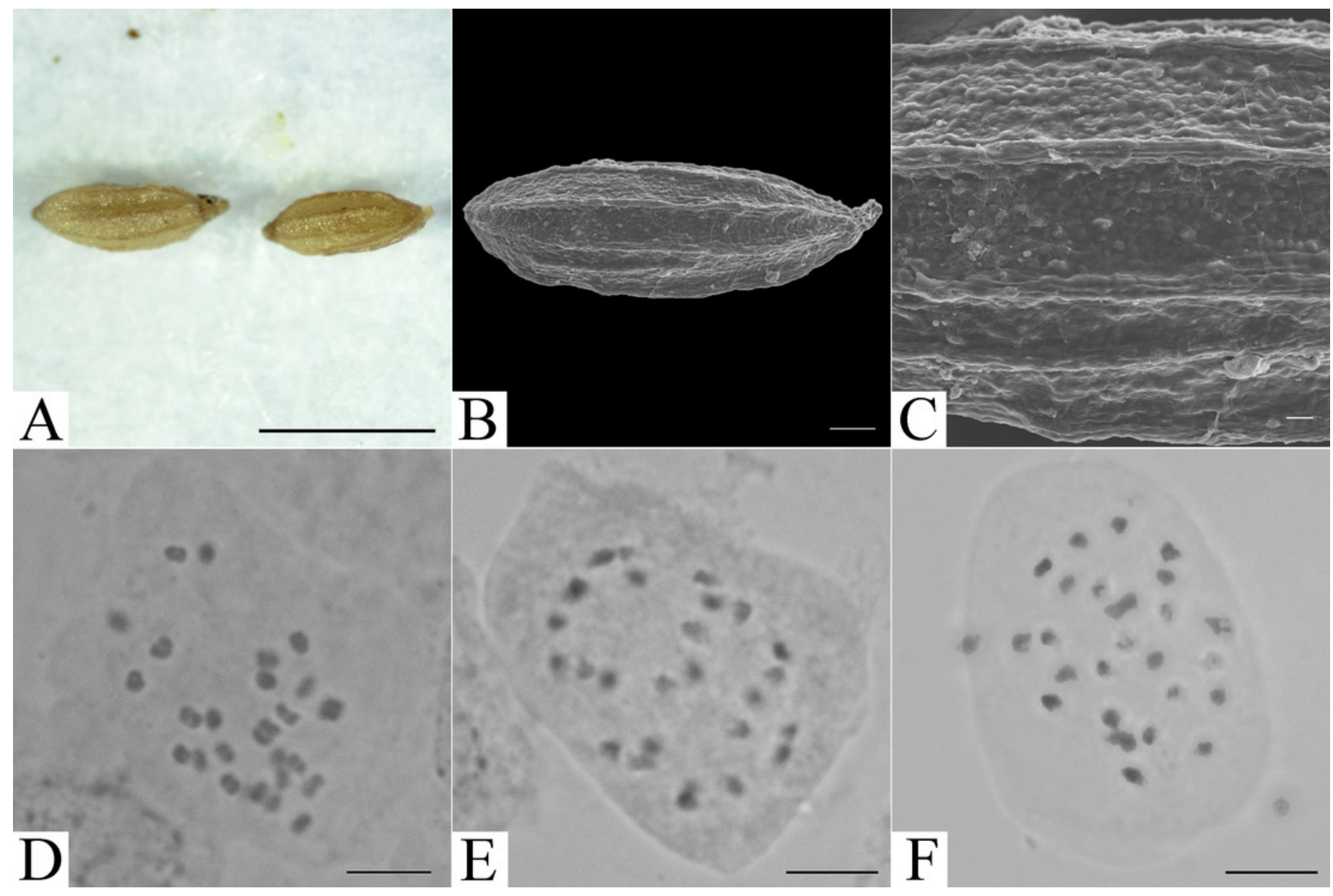




\section{Figure 4}

Illustration of Elatostema qinzhouense.

Figure 4. Illustration of Elatostema qinzhouense. (A) habit; (B) staminate and pistillate inflorescences at subsequent nodes of monoecious stem ; (C) stipule and furfuraceous stem; (D) leaves; (E) staminate inflorescence viewed from below showing involucre bracts; (F) staminate flower; (G) pistillate inflorescence viewed from below showing involucre bracts; $(H)$ achene. Illustration by Juliet Beentje. 


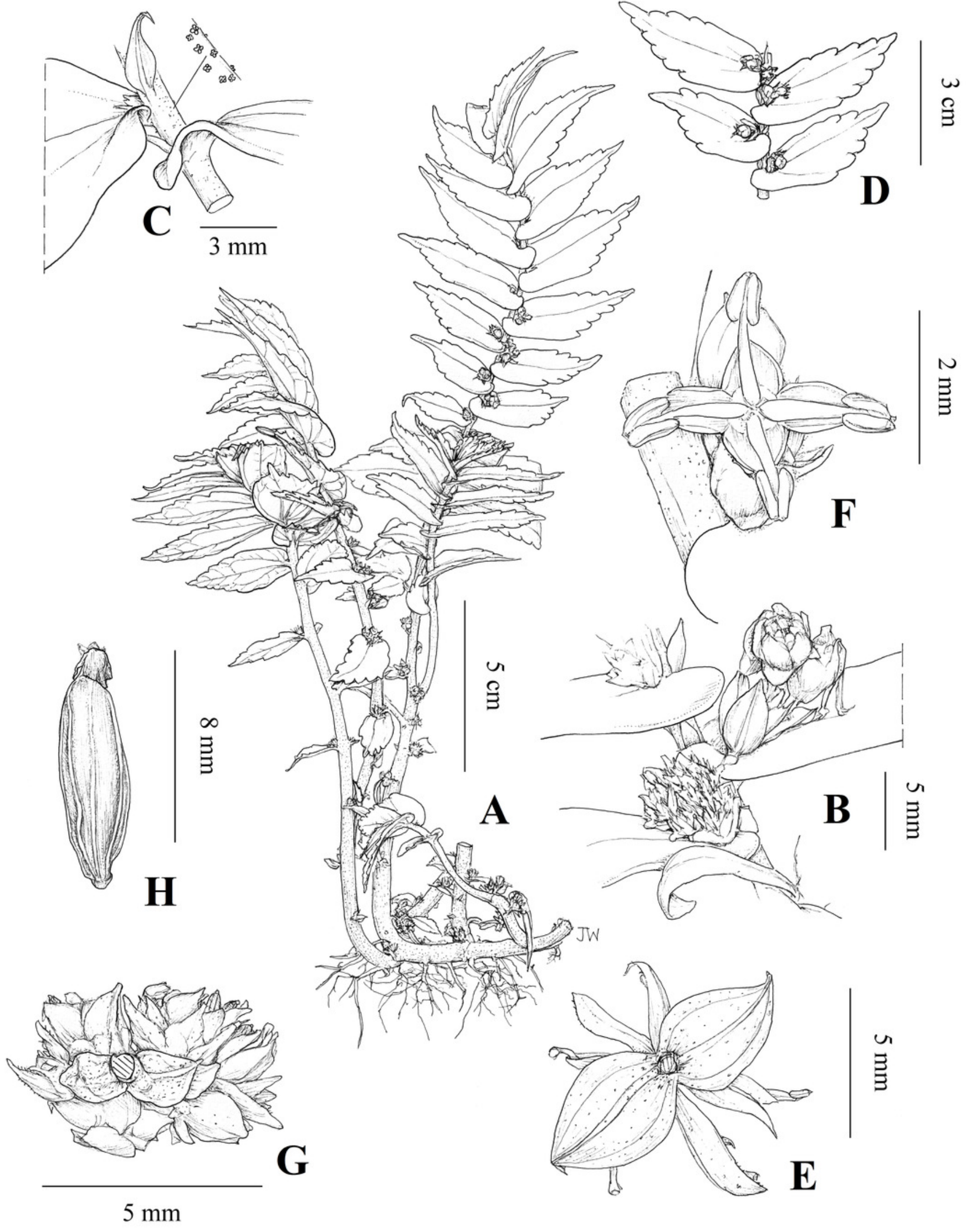


Figure 5

Plate of Elatostema qinzhouense

Figure 5. Plate of Elatostema qinzhouense: (A) habitat; (B) habit; (C) leave base and stipule; (D) staminate inflorescence; (E) staminate flower; (F) pistillate inflorescence. Photos by LongFei Fu \& Bo Pan. 

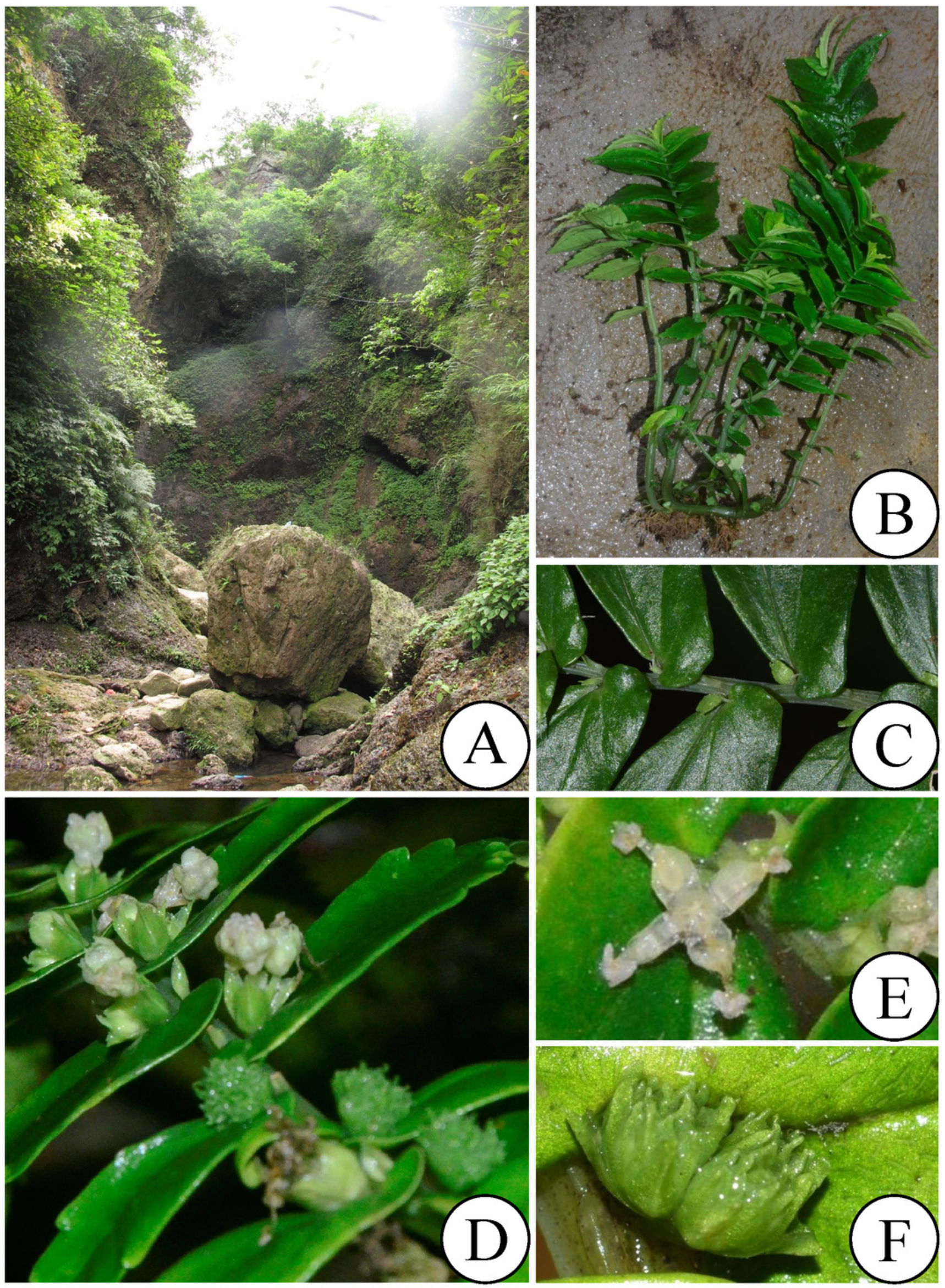